\title{
Malignant lymphoma subgroups from Zaria, Nigeria, reveal absence of HIV/AIDS-related plasmablastic lymphomas and HHV-8-related lymphoproliferative disorders
}

Yawale lliyasu ${ }^{1,3}$, Weiqiang Zhao ${ }^{2,3}$, Leona W Ayers ${ }^{2,3^{*}}$

From $12^{\text {th }}$ International Conference on Malignancies in AIDS and Other Acquired Immunodeficiencies (ICMAOI)

Bethesda, MD, USA. 26-27 April, 2010

\section{Background}

Prevalence of non-Hodgkin's lymphoma (NHL) subgroups throughout Africa, particularly among persons with HIV/AIDS, is unknown but increases in Burkitt lymphoma, plasmablastic lymphoma, and HHV-8 proliferation disorders have been noted. SSALC, an AIDS and Cancer Specimen Resource (ACSR/NCI) project, seeks to define indigenous sub-Saharan NHL subtypes using WHO classification (2008). Omoti (Univ. Benin 2007) defined an overall malignant lymphoma (ML) rate: 13.4/ 100,000 (1990s) including 17\% Hodgkin's disease and
83\% NHL but subgroups were not defined. Because regional HIV/AIDS prevalence is high, we subgrouped NHL and reviewed lymph node hyperplasia using stored material from Ahmadu Bello University Teaching Hospital in Zaria, Nigeria, to look for HIV/AIDS-associated lymphoid malignancies.

\section{Materials and methods}

Fifty-seven paraffin blocks were used to construct a tissue microarray (TMA), and whole tissue sections were H\&E stained for morphology. TMA sections were stained

Table 1 Cases by diagnostic subgroup

\begin{tabular}{|c|c|c|c|c|}
\hline \multicolumn{3}{|l|}{ Subgroups } & \multirow{2}{*}{$\begin{array}{l}\frac{\mathbf{N}}{19} \\
\end{array}$} & \multirow{2}{*}{$\begin{array}{l}\% \mathrm{NHL} \\
51\end{array}$} \\
\hline & Burkitt lymphoma & & & \\
\hline & Lymphoblastic lymphoma: (pre-B) & & 1 & 3 \\
\hline & Angioimmunoblastic T-cell lymphoma & & 1 & 3 \\
\hline & Follicular lymphoma & & 6 & 16 \\
\hline $\mathrm{NHL}$ & Marginal zone lymphoma & & 1 & 3 \\
\hline \multirow[t]{5}{*}{$M L$} & Lymphoma not otherwise specified (NOS) & & 2 & 5 \\
\hline & B-cell lymphoma, EBV+ & & 1 & 3 \\
\hline & Diffuse large B-cell lymphoma & Activated B cell & 4 & 11 \\
\hline & & NOS & 1 & 3 \\
\hline & Malignant infiltrate (HHV-8 negative) & & 1 & 3 \\
\hline \multicolumn{2}{|c|}{ Hodgkin's disease } & & 5 & \\
\hline \multicolumn{2}{|l|}{ Reactive/normal tissue } & & 15 & \\
\hline \multicolumn{2}{|l|}{ Total } & & 57 & \\
\hline
\end{tabular}

\footnotetext{
* Correspondence: ayers.1@osu.edu

${ }^{2}$ Department of Pathology, The Ohio State University, Columbus, OH, USA

Full list of author information is available at the end of the article
} 
using 30 monoclonal antibodies for common NHL antigens and Lana-1 for HHV-8 (immunohistochemical, IHC); in situ hybridization (ISH) for EBV-encoded RNA, kappa/lambda light chains (Ventana, Tucson, AZ), and fluorescent in situ hybridization (FISH) c-myc $t(8 ; 14)$ (Abbott/Vysis, Downer's Grove, IL).

\section{Results}

There were $43 \mathrm{ML}$ and 14 hyperplasic lymph nodes or reactive tissues. One lymph node was suspected for Castleman's disease but Lana-1 was negative. Table 1 lists ML subgroups.

\section{Conclusions}

Subgrouping ML with Hodgkin's disease (12\%) and NHL (88\%) is similar to the 2007 report from nearby Benin University. Burkitt lymphoma was the most common NHL at $51 \%$ followed by follicular lymphoma $16 \%$ and diffuse large B-cell lymphomas $14 \%$. With the exception of Burkitt lymphoma, which is endemic in Nigeria, other NHL commonly associated with HIV/ AIDS such as plasmablastic lymphoma and HHV-8 lymphoproliferative disorders were not identified.

\section{Acknowledgements}

This article has been published as part of Infectious Agents and Cancer Volume 5 Supplement 1, 2010: Proceedings of the $12^{\text {th }}$ International Conference on Malignancies in AIDS and Other Acquired

Immunodeficiencies (ICMAOI). The full contents of the supplement are available online at http://www.biomedcentral.com/1750-9378/5?issue=S1.

\section{Author details}

'Department of Pathology, Ahmadu Bello University Teaching Hospital, Zaria, Nigeria. ${ }^{2}$ Department of Pathology, The Ohio State University, Columbus, OH, USA. ${ }^{3}$ Sub-Saharan Africa Lymphoma Consortium (SSALC/NCI).

Published: 11 October 2010
Submit your next manuscript to BioMed Central and take full advantage of:

- Convenient online submission

- Thorough peer review

- No space constraints or color figure charges

- Immediate publication on acceptance

- Inclusion in PubMed, CAS, Scopus and Google Scholar

- Research which is freely available for redistribution

Submit your manuscript at www.biomedcentral.com/submit 